\title{
KOMUNIKASI ANTARBUDAYA DI PONDOK PESANTREN (Studi Kasus di Pondok Pesantren Putri Miftahul Ulum Banyuputih Lumajang)
}

\author{
Solehati Ilmaniya ${ }^{1)}$, Rio Febriannur Rachman ${ }^{2)}$ \\ ${ }^{1,2)}$ Institut Agama Islam Syarifuddin Lumajang \\ E-mail: ilmaniya42@gmail.com ${ }^{1)}$, riofrachman21@ gmail.com ${ }^{2)}$
}

\begin{abstract}
ABSTRAK
Artikel ini membahas tentang komunikasi antarbudaya di Pondok Pesantren. Pondok pesantren adalah sentra pendidikan berbasis agama yang memiliki asrama tempat para santri menginap. Mereka berasal dari berbagai latar belakang. Fenomena komunikasi antarbudaya yang ada di sana menarik untuk dicermati. Tujuan penelitian ini adalah menjelaskan bagaimana pola, perilaku, dan hambatan komunikasi antarbudaya di Pondok Pesantren. Riset ini memakai metode kualitatif, dengan pendekatan studi kasus. Lokasi penelitian adalah Pondok Pesantren Putri Miftahul Ulum Banyuputih Lumajang. Penelitian ini mengumpulkan data dengan cara observasi lapangan pada 8 maret sampai 16 maret 2020. Selain itu, dilakukan pula wawancara mendalam pada dua orang ustadzah atau pengurus dan tiga santri perempuan masing-masing dari Madura, Sumatera, dan Jawa. Analisis data dilakukan dengan mereduksi, menyajikan, dan merumuskan kesimpulan. Hasil dari penelitian ini adalah, pertama; santri saling menjaga etika dalam berperilaku komunikasi, kedua; pola komunikasi antarsantri umumnya dua arah, sedangkan kalau santri tengah berhadapan dengan Ibu Nyai (pengasuh Pondok Pesantren) atau ustadzah akan memakai pola satu arah, ketiga; hambatan yang mencolok dalam proses komunikasi adalah hambatan semantik atau bahasa. Untuk bisa memgatasi persoalan bahasa di Pondok Pesantren itu, para santri selalu bertanya dengan santri maupun ustadzah dengan bahasa Indonesia. Penelitian ini diharapkan bisa menambah khazanah riset tentang komunikasi antarbudaya di Pondok Pesantren.
\end{abstract}

Kata Kunci: Komunikasi, Budaya, Pondok Pesantren 


\begin{abstract}
This article discusses intercultural communication in Islamic boarding schools. Islamic boarding school is a religious-based education center which has a dormitory where students stay. They come from various backgrounds. The phenomenon of intercultural communication in there, is interesting to be observed. The purpose of this study was to explain how the patterns, behavior, and barriers of intercultural communication in Islamic boarding schools. This research used a qualitative method, with a case study approach. The research location was Miftahul Ulum Banyuputih Lumajang, Female Islamic Boarding School. This study collected data by field observations on 8 March to 16 March 2020. In addition, in-depth interviews were also conducted with two religious teachers or administrators and three female students from Madura, Sumatra and Java. Data analysis was performed by reducing, presenting, and formulating conclusions. The results of this study are, first; student maintain mutual ethics in behaving in communication, second; communication patterns between students were generally two-way communication, whereas if student are dealing with Ibu Nyai (caretaker of the Islamic Boarding School) or religious teacher, they will use a one-way communication, third; a striking barrier in the communication process is the semantic or language barrier. To be able to overcome the language problem at the Islamic Boarding School, the students always ask the other students or teachers in Bahasa. This research is expected to be able enrich the research treasure about intercultural communication in Islamic boarding schools.
\end{abstract}

Keywords: Communication, Culture, Islamic Boarding Schools

\title{
A. PENDAHULUAN
}

Hubungan sosial selalu ditandai dengan proses di mana seorang anggota masyarakat yang baru akan mempelajari norma-norma dan kebudayaan masyarakat di mana dia menjadi anggota suatu masyarakat. ${ }^{1}$ Indonesia ini merupakan negara dengan jumlah penduduk nomor empat terbesar setelah Cina, India dan Amerika Serikat, Indonesia memiliki

1 Vita Fitriani, "Komunikasi Antar Budaya Dalam Kehidupan Pesantren” (Skripsi, Program Studi Ilmu Komunikasi Fakultas Dakwah Institut Agama Islam Negeri Sunan Ampel Surabaya, 2013) 
jumlah etnis dan subetnis tidak kurang dari 1.072. Fakta tersebut membuat Indonesia dikenal sebagai negara multikultural dengan komunitas masyarakat beragam yang hidup berdampingan di desa maupun di kota. ${ }^{2}$

Kehidupan sosial dalam bermasyarakat tentunya tidak selalu berjalan lancar seperti yang diinginkan. Banyak bahkan sering terjadi masalah-masalah atau konflik sosial di sekitar kita. Pemerintah berupaya mereduksi masalah di masyarakat. Baik dengan pengembangan masyarakat di bidang ekonomi rakyat ${ }^{3}$, maupun memajukan industri kreatif demi kesetaraan warga ${ }^{4}$. Pemerintah juga berinovasi dengan membuat terobosan di bidang pendidikan, termasuk dalam lingkup pendidikan bagi yang berkebutuhan khusus ${ }^{5}$. Meski demikian, masalah sosial tentu tetap masih ada, sesuai perkembangan zaman. Masalah sosial ini tentunya dapat berdampak buruk pada tingkat kesejahteraan masyarakat karena hubungan sosial tidak dapat berjalan dengan baik. ${ }^{6}$ Masalah sosial berhubungan erat dengan nilai-nilai sosial dan lembaga kemasyarakatan di mana nilai itu biasanya berfungsi sebagai pedoman tertinggi bagi kelakuan manusia. ${ }^{7}$

Maka dari itu dapat dikatakan bahwa setiap individu dalam melaksanakan aktifitas sosialnya selalu berdasarkan serta berpedoman kepada nilai-nilai yang ada dalam masyarakat itu sendiri. Maksut dari nilai-nilai tersebut sangat banyak mempengaruhi tindakan dan perilaku manusia, baik secara individu, kelompok atau masyarakat secara menyeluruh tentang baik buruknya. Masalah sosial timbul dari kekurangan dalam diri manusia atau kelompok sosial yang bersumber

${ }^{2}$ Agus Salim, Stratifikasi etnik, (Yogyakarta: Tiara Wacana, 2006), 6

${ }^{3}$ Rio Febriannur Rachman. (2019). Optimalisasi Media Digital Berbasis Kemaslahatan Umat dalam Program Pahlawan Ekonomi Surabaya. IQTISHODUNA: Jurnal Ekonomi Islam 8 (2), 273-292.

${ }^{4}$ Rio Febriannur Rachman. (2019). Pengembangan Industri Kreatif Berbasis Media

Digital di Surabaya dalam Perspektif Islam. KOMUNITAS, 10(2), 157-176.

${ }^{5}$ Rio Febriannur Rachman. (2020). Kebijakan Pendidikan Anak Berkebutuhan Khusus

Di Surabaya Dalam Perspektif Islam. Bidayatuna: Jurnal Pendidikan Guru

Mandrasah Ibtidaiyah 3 (1), 125-143.

${ }^{6}$ Koentjaraningrat, Kebudayaan Mentalitas dan Pembangunan, (Jakarta: PT

Gramedia Pustaka, 2002), 9.

${ }^{7}$ Koentjaraningrat, Kebudayaan Mentalitas dan Pembangunan, (Jakarta: PT

Gramedia Pustaka, 2002), 9. 
pada faktor-faktor ekonomis, biologis, biopsikologis dan kebudayaan. Setiap masyarakat mempunyai norma-norma yang bersangkut-paut dengan kesejahteraan kebendaan, kesehatan fisik, kesehatan mental, serta penyesuaian diri individu atau kelompok sosial. ${ }^{8}$

Sebagai makhluk sosial, manusia tidak akan hidup tanpa bantuan orang lain, sikap saling ketergantungan ini tidak dapat berjalan dengan baik tanpa adanya komunikasi yang baik. Manusia tidak akan mengalami perkembangan fisik dan psikis yang baik jika ia mengasingkan diri dari masyarakat sekitarnya. Disebabkan seluruh hidup manusia tidak akan terlepas dari komunikasi. Bahkan bisa dikatakan komunikasi adalah cara manusia meng (ada) dalam dunianya. ${ }^{9}$

Kebutuhan manusia dapat terpenuhi jika manusia berkomunikasi dengan orang lain, jika dia dapat berkomunikasi dengan baik maka dapat mencapai kebutuhannya. Di era kekinian, optimalisasi teknologi memang terus dilakukan dalam upaya berkomunikasi ${ }^{10}$. Meski demikian, komunikasi tatap muka tetap urgen dan fundamental dalam interaksi antar manusia. Komunikasi antar manusia termasuk komunikasi Lintas budaya yang baik sangat ditentukan oleh pamahaman makna ${ }^{11}$ terutama meletakkan makna tersebut dalam nilai kebudayaan yang siap diterima sebagaimana kehidupan di Pondok Pesantren. ${ }^{12}$

Kehidupan di pondok pesantren tidak bisa lepas dari interaksi sosial yang terjadi antara anggota masyarakat pesantren. Suatu interaksi sosial tidak mungkin terjadi apabila tidak memenuhi dua syarat yaitu: ${ }^{13}$ adanya kontak sosial dan komunikasi, Kontak sosial dapat berlangsung dalam tiga bentuk yaitu antar individu dengan individu, individu dengan

\section{${ }^{8}$ Soerjono, Soekanto, Sosiologi Suatu Pengantar, (Jakarta: PT Rajagrafindo} Persada, 2012), 314 .

${ }^{9}$ Nuruddin, Sistem Komunikai Indonesia (Jakarta: PT Raja Grafindo Persada, 2010), 44.

${ }^{10}$ Rio Febriannur Rachman. Optimalisasi Teknologi Komunikasi Informasi Command Center Bagi Efektifitas Tenaga Kesejahteraan Sosial Kecamatan, Dakwatuna: Jurnal Dakwah dan Komunikasi Islam 5 (2), 170-180

${ }^{11}$ Vita Fitriani, Komunikasi Antar Budaya Dalam Kehidupan Pesantren Skripsi Program Studi Ilmu Komunikasi Fakultas Dakwah Institut Agama Islam Negeri Sunan Ampel Surabaya 2013

${ }^{12}$ Alo Liliweri, Makna Budaya dalam Komunikasi Antar Budaya (Yaogyakarta: PT LKiS Printing Cemerlang, 2009), 50.

${ }^{13}$ Soerjono Soekanto, Faktor-Faktor Dasar Interaksi Sosial dan Kepatuhan Pada Hukum. Hukum Nasional, Nomor 25, 1974 
kelompok maupun kelompok dengan kelompok. sedangkan arti terpenting komunikasi adalah seseorang memberikan tafsiran pada prilaku orang lain (yang berwujud pembicaraan, gerak-gerak badaniah atau sikap), perasaan-perasaan apa yang ingin disampaikan oleh orang tersebut.

Dengan adanya komunikasi, maka sikap-sikap dan perasaanperasaan itu dapat diketahui orang lain. Komunikasi di pondok pesantren yang terjalin antara para santri memiliki ciri khas tersendiri. Heterogenitas para santri yang ada di dalamnya menimbulkan perbedaan komunikasi dengan komunikasi di luar pesantren. Heterogenitas di sini tercermin dari berbagai sisi seperti etnis, bahasa, suku maupun ras. Dari komunikasi antarbudaya pada dasarnya mengacu pada realitas keragaman budaya dalam masyarakat yang masing-masing memiliki etika, tata cara dan pola komunikasi yang beragam pula. Seluruh proses komunikasi pada akhirnya menggantungkan keberhasilan pada tingkat ketercapaian tujuan komunikasi, yakni sejauh mana para partisipan memberikan makna yang sama atas pesan yang dipertukarkan. ${ }^{14}$

Sesuai dengan kebutuhan manusia sekarang ini yang telah bertempat di mana hidup di zaman dengan perkembangan teknologi serba canggih sehingga pengaksesan informasi dapat lebih mudah ditingkatkan. Bahkan, media massa juga bisa dengan lancar mengirimkan pesan bahkan berimbas pada distorsi nilai, termasuk di ranah keagamaan, tak terkecuali keislaman ${ }^{15}$. Charles Tilly seorang ahli sosiolog kependudukan mengatakan ada beberapa faktor yang mendorong terjadinya migrasi yaitu keadaan satuan imigran, situasi dan kondisi di daerah asal, situasi dan kondisi di daerah tujuan dan situasi dan kondisi sosial, ekonomi, politik serta jaringan yang terkait di dalamnya. ${ }^{16}$

Persaingan hidup di kota membuat sebagian para orang pindahan khususnya para mahasiswa atau mahasiswi lebih memilih tinggal di

\footnotetext{
${ }^{14}$ Alo Liliweri, Makna Budaya, 227

${ }^{15}$ Rio Febriannur Rachman. Perspektif Karen Armstrong Tentang Islamofobia Di

Media Barat. Dakwatuna: Jurnal Dakwah dan Komunikasi Islam 4 (2), 282-291

${ }^{16}$ Alo, Liliweri, Prasangka \& Konflik Komunikasi Lintas Budaya Masyarakat Multikultural (Yogyakarta: PT LKiS, 2005), 142.
} 
pondok pesantren, karena pondok pesantren di samping sebagai lembaga pendidikan dan dakwah Islam ternyata telah banyak yang berfungsi dan berperan sebagai lembaga pengembangan msyarakat. Pada umumnya pondok pesantren memiliki potensi untuk maju dan berkembang memperdayakan diri dan masyarakat lingkunganya. ${ }^{17}$

Selain itu kehidupan di pondok pesantren juga biasanya dapat menjalin ikatan persaudaraan yang kuat sehingga dapat mengurangi tingkat kekhawatiran hidup di kota orang. Sekelompok orang yang pindah dari satu lingkungan budaya ke lingkungan budaya yang lain mengalami proses sosial budaya yang dapat menpengaruhi mode adaptasi dan pembentukan identitasnya, kebudayaan daerah tujuan telah memberi kerangka kultural baru yang karenanya turut pula memberikan definisi-definisi dan ukuran nilai-nilai bagi kehidupan sekelompok orang. Proses reproduksi kebudayaan merupakan proses aktif yang menegaskan keberadaanya dalam kehidupan sosial sehinggamengharuskan adanya adaptasi bagi kelompok yang memiliki latar belakang kebudayaan yang berbeda. ${ }^{18}$

Pondok pesantren Miftahul Ulum Banyuputih Kidul merupakan Pondok Pesantren Salafi terbesar di Kabupaten Lumajang. Santrisantrinya berasal dari berbagai daerah di Indonesia dengan kebudayaan yang berbeda-beda sesuai daerah asal masing-masing, ada yang berasal dari etnis Jawayang meliputi berbagai daerah/kota diantaranya Lumajang, Probolinggo, Pasuruan, Jember. Kemudian ada juga yang berasal dari etnis Madura, Sumatera, Kalimantan, Riau. ${ }^{19}$ Komunikasi antarbudaya yang terjadi di Pondok Pesantren Miftahul Ulum Banyuputih Kidul Lumajang terjadi hampir setiap hari, perbedaan etnis pada mereka menimbulkan perbedaan pula dalam prilaku komunikasi. Dimana Santri yang berasal dari etnis Madura dan Sumatera merupakan entis pendatang yang memberikan warna baru yang dibawa dari kebudayaan keseharian mereka. Intensitas komunikasi di pondok

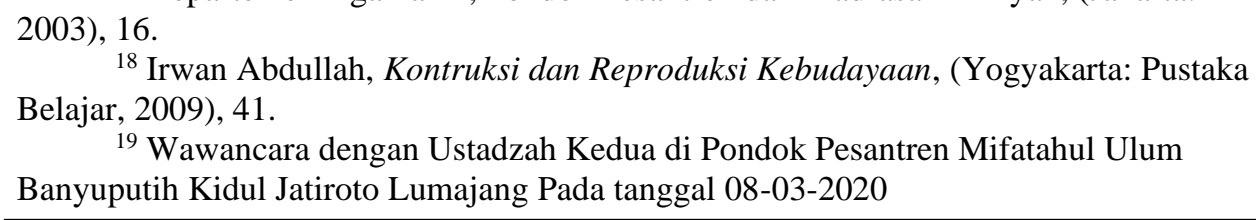

${ }^{18}$ Irwan Abdullah, Kontruksi dan Reproduksi Kebudayaan, (Yogyakarta: Pustaka Belajar, 2009), 41.

${ }^{19}$ Wawancara dengan Ustadzah Kedua di Pondok Pesantren Mifatahul Ulum Banyuputih Kidul Jatiroto Lumajang Pada tanggal 08-03-2020

${ }^{17}$ Departemen Agama RI, Pondok Pesantren dan Madrasah Diniyah, (Jakarta: 
pesantern Banyuputih Kidul Lumajang bisa dibilang sangat tinggi karena dalam kehidupan sehari-hari mereka tinggal dalam ruangan atau kamar yang sama dengan jumlah santri kurang lebih dua ribu santri. ${ }^{20}$

Dalam hal aktifitas keseharian, tentu saja masing-masing melaksanakannya sesuai dengan nilai-nilai dan patokan-patokan yang mencerminkan budayanya sendiri. Keadaan tersebut terkadang berakhir dengan terjadinya tidak bersatu padu. Kebutuhan yang berbeda-beda dan yang bersamaan diantara dua pihak atau lebih secara potensial dapat menyebabkan konflik, walaupun hal itu tidak selalu terjadi. ${ }^{21}$ Kaitan langsung antara konflik dan kebutuhan sangat tergantung pada bagaimana kebutuhan tersebut diterjemahkan ke dalam keinginankeinginan dan tindakan pemenuhanya. ${ }^{22}$

Begitu juga yang terjadi di pondok pesantren Miftahul Ulum Banyuputih Lumajang di mana dalam tindakan pemenuhan kebutuhannya, para santri memiliki cara yang berbeda-beda tergantung budaya mereka masing-masing yang secara potensial dapat menyebabkan konflik. Berdasarkan pengamatan tersebut, peneliti tertarik untuk mengupas tentang komunikasi antarbudaya di pondok pesantren Miftahul Ulum Banyuputih Kidul, Jatiroto, Lumajang. Fokus kajian riset ini adalah komunikasi antarbudaya para santri dari Madura, Jawa, dan Sumatera. Tujuannya, menjelaskan tentang pola, perilaku dan hambatan komunikasi lintas Budaya Antara Santri Madura, Jawa dan Sumatera di Pondok Pesantren Baanyuputih Kidul Jatiroto Lumajang. Penelitian ini diharapkan bisa menjadi suatu masukan dan pengembangan penelitian dalam memperkaya wacana keilmuan Islam yang berhubungan dengan komunikasi antarbudaya.

Penelitian ini bakal melengkapi khazanah penelitian mengenai Pondok Pesantren yang sudah lama ada selama ini. Antara lain, penelitian mengenai pembelajaran di Pondok Pesantren yang mesti

${ }^{20}$ Wawancara dengan Ustadzah Pertama di Pondok Pesantren Mifatahul Ulum Banyuputih Kidul Jatiroto Lumajang pada tanggal 08-03-2020

${ }^{21}$ Wawancara dengan Santri Kedua di Pondok Pesantren Mifatahul Ulum Banyuputih Kidul Jatiroto Lumajang pada tanggal 08-03-2020

${ }^{22}$ Robby I, Chandra, Konflik Dalam Hidup Sehari-hari, (Yogyakarta: Kansius, 1992,), 27. 
mampu menghadapi kemajuan zaman $^{23}$, relevansi sistem pendidikan pesantren tradisional dalam era modernisasi ${ }^{24}$, dan eksistensi sistem pesantren salafiyah dalam menghadapi era modern ${ }^{25}$. Riset ini mengupas tentang fenomena yang terjadi di Pondok Pesantren dari sudut pandang ilmu komunikasi, dalam bidang komunikasi antarbudaya.

\section{B. METODE PENELITIAN}

Penelitian ini menggunakan metode kualitatif ${ }^{26}$ dengan pendekatan studi kasus. Penelitian studi kasus berupaya menelaah sebanyak mungkin data mengenai subjek yang diteliti. ${ }^{27}$ Penelitian ini mengumpulkan data dengan cara observasi lapangan pada 8 maret sampai 16 maret 2020. Observasi yang dilakukan ialah dengan cara mengamati dan mencermati serta merekam perilaku secara sistematis untuk suatu tujuan tertentu. Observasi merupakan teknik pengumpulan data yang dilakukan dengan cara pengamatan dan pencatatan secara sistematis, logis, objektif dan rasional mengenai berbagi fenomena. ${ }^{28}$

Pada dasarnya tujuan observasi adalah untuk mendeskripsikan lingkungan yang diamati, aktivitas-aktivitas yang berlangsung, individuindividu yang terlibat dalam lingkungan tersebut dan perilaku yang dimunculkan serta makna kejadin berdasarkan perspektif individu yang terlibat tersebut. ${ }^{29}$ Dalam penelitian ini observasi dilakukan dengan cara pengamatan dan pencatatan mengenai komunikasi lintas budaya santri. Selain itu, dilakukan pula wawancara mendalam pada ustadzah atau pengurus dan santri perempuan dari etnis Jawa, Madura dan Sumatera di Pondok Pesantren Miftahul Ulum Banyuputih Kidul Jatiroto Lumajang.

${ }^{23}$ Ahmad Syauqi Fuady, Pembaharuan Sistem Pendidikan Di Pesantren, AlInsyiroh: Jurnal Studi Keislaman 6(1), 101-114

${ }^{24}$ M. Syukron Djazilam, Relevansi Sistem Pendidikan Pesantren Tradisional Dalam Era Modernisasi, Al-Insyiroh: Jurnal Studi Keislaman 5(1), 89-105

${ }^{25}$ M. Kholil Baita Putra, Eksistensi Sistem Pesantren Salafiyah Dalam Menghadapi Era Modern, Al-Insyiroh: Jurnal Studi Keislaman 1(1), 87-104

${ }^{26}$ Imam Suprayoga, Tabrani, Metode Penelitian Sosial Agama, (Bandung: Remaja Rosdakarya, 2001) hlm. 161.

${ }^{27}$ Rusdi Pohan, Metodologi Penelitian Pendidikan (Yogyakarta: Lanakarya, 2007), 7

${ }^{28}$ Zainal Arifin, Penelitian Pendidikan (Metode Dan Paradigma Baru) (Bandung: PT Remaja Rosdakarya, 2011), 23.

${ }^{29}$ Haris Herdiansyah, Metodologi Penelitian Kualitatif (Jakarta: Salemba Humanika, 2011), 131-132. 
Detailnya, ada dua ustadzah; yang pertama orang kepercayaan Ibu Nyai (Nyai adalah pengasuh pondok pesantren) untuk mengurus pondok dan santrinya. dia menetap di pondok selama 18 tahun lebih, ustadzah tersebut merupakan santri paling lama mondoknya, beliau disana juga sebagai guru madrasah. Yang kedua; sudah mengabdi di pondok selama 17 tahun dan asli Sumatera. Sedangkan santri perempuan yang diwawancarai pertama dari etnis Madura, kedua dari etnis Sumatera, dan ketiga dari etnis Jawa. Wawancara adalah percakapan yang dilakukan oleh dua pihak, yaitu pewawancara (interviewer) yang mengajukan pertanyaan dan terwawancara (interviewee) yang memberikan jawaban atas pertanyaan tersebut. ${ }^{30}$

Pada penelitian ini peneliti menggunakan metode wawancara semi terstruktur yaitu pertanyaan terbuka namun ada batasan tema dan alaur pembicaraan, kecepatan wawancara dapat diprediksi, fleksibel tetapi terkontrol, ada pedoman wawancara yang dijadikan patokan dalam alur, urutan dan penggunaan kata, dan tujuan wawancara adalah untuk memahami komunikasi lintas budaya santri. Di samping itu, untuk menguatkan hasil observasi dan wawancara, dilakukan pula pembacaan literatur yang berhubungan dengan topik penelitian guna memerkaya pembahasan. Cara ini bertujuan mencari data melalui peninggalan tertulis, seperti arsip dan termasuk juga buku-buku tentang pendapat, teori dan bahan lain-lain yang berhubungan dengan masalah penelitian. ${ }^{31}$

Analisis data dilakukan dengan, pertama, mereduksi data, yakni merangkum, memilih hal-hal yang pokok serta memfokuskan pada halhal yang penting dan membuang yang tidak perlu. ${ }^{32} \mathrm{Hal}$ ini bertujuan agar memberikan gambaran yang jelas sehingga akan mempermudah peneliti untuk melakukan pengumpulan data selanjutnya. Data peneliti yang harus direduksi meliputi data wawancara, dokumentasi dan observasi. Kedua, penyajian data, yaitu mendeskripsikan data yang diperoleh dari peneltian dilapangan.Penyajian data dapat dilakukan 2008), 186.

${ }^{30}$ Lexy J. Moeloeng, Metode Penelitian Kualitatif (Bandung: Remaja Rosdakarya,

${ }^{31}$ S. Margono, Metodologi Penelitian Pendidikan, (Jakarta: Rineka Cipta, 2005), 165

${ }^{32}$ Sugiyono, Metode Penelitian Pendidikan Pendekatan Kuantitatif, Kualitatif dan $R \& D$, (Bandung: Alfabeta, 2010) 338. 
dalam bentuk uraian singkat atau teks yang bersifat naratif. ${ }^{33}$ Adanya penyajian data akan mempermudah peneliti untuk memahami apa yang terjadi dan merencanakan kerja selanjutnya berdasarkan apa yang telah dipahami tersebut. Ketiga, proses penarikan kesimpulan dengan cara mengambil inti informasi yang tersusun dalam penyajian data. Sehingga dalam penelitian ini peneliti dapat mengambil kesimpulan yang dapat menjawab rumusan masalah yang ada.

\section{HASIL DAN PEMBAHASAN}

Komunikasi Lintas Budaya dalam kehidupan pesantren bagi santri Miftahul Ulum Banyuputih Kidul menunjukkan tidak banyak adanya perbedaan antara santri Madura, Jawa, Maupun Sumatera, mereka saling memahami satu sama lain, jika saling berkomunikasi satu sama lain, dan ada pembicaraan yang tidak dipahami maka meraka akan menggunakan bahasa nasional, yang mempersulit mengartikan bahasa hanya ada dalam pembacaan kitab, karena di Pondok Pesantren Mifatahul Ulum Banyuputih Kidul menggunakan bahasa Madura, dan terkadang pula santri yang berasal dari Madura juga sedikit tidak dimengerti, karena bahasa kitab dan bahasa Maduranya yang di pakai setiap hari agak sedikit berbeda, kalau bahasa Madura yang di kitab lebih kental dibanding bahasa yang dipakai setiap harinya. ${ }^{34}$

Secara garis besar berdasarkan temuan dalam penelitian ini, merujuk pada hasil penyajian data, maka di sini akan dipaparkan analisis data yang akan menghasilkan temuan-temuan penelitian yang mengacu pada fokus penelitian yakni perilaku dan pola komunikasi serta faktor pendukung dan penghambat komunikasi lintas budaya antara etnis Jawa, Madura dan Sumatera di pondok pesantren Miftahul Ulum Banyuputih Kidul Jatiroto Lumajang. Perilaku komunikasi Lintas budaya di Pondok Pesantren Miftahul Ulum Banyuputih Kidul dapat dilihat dari dua konteks, yaitu konteks sosial dan konteks kemanusiaan.

Dilihat dari konteks sosial, perilaku komunikasi Lintas budaya yang terjadi di pondok pesantren Miftahul ulum Banyuputih Kidul menunjukkan tidak banyak adanya perbedaan atau diskriminasi antara

\footnotetext{
${ }^{33}$ Sugiyono, Metode Penelitian Pendidikan Pendekatan Kuantitatif, Kualitatif dan $R \& D, 341$.

${ }^{34}$ Wawancara dengan Santri Pertama (16/03/2020)
} 
santri yang beretnis Jawa, Madura maupun Sumatera. Mereka samasama saling menghargai atau menghormati budaya satu sama lain. Dalam kehidupan sehari-hari mereka bergaul tanpa membedakan dari mana asal budaya mereka, kedekatan mereka lebih cenderung berdasarkan satu kamar mereka yang di dalam kamarnya tersebut berasal dari bermacam daerah .Selain itu kedekatan juga banyak dipengaruhi oleh faktor satu kelas karena mereka lebih sering menjalin komunikasi. ${ }^{35}$ Namun tidak dipungkiri, terkadang terlihat juga kedekatan yang terjalin karena faktor etnis, terlebih antara etnis Jawa dan Madura karena letak geografis antara Madura dan Jawa lebih dekat dibanding dengan Sumatera dan juga karena memang sebenarnya Madura masih termasuk dalam pulau Jawa.

Dari konteks kemanusiaan, komunikasi Lintas budaya yang terjadi antara etnis Jawa, Madura dan Sumatera di Pondok Pesantren Mifatahul Ulum Banyuputih Kidul menunjukkan bahwa nilai-nilai kemanusiaan yang mereka terapkan dalam kehidupan sehari-hari di dalam perbedaan budaya adalah mereka juga saling menjaga sikap atau etikanya. Meskipun mereka mempunyai jalan pikiran yang tidak sama dan juga sistem beretika yang hanya berlaku bagi kelompok atau etnis tertentu, seperti Madura, Jawa dan Sumatera mereka tetap bisa saling menjaga kerukunan meskipun terkadang terjadi kesalapahaman perbedaan budaya. Mereka bisa menyelesaikan dengan kesadaran mereka masingmasing bahwa harus bisa menjaga sikap menghargai budaya lain dan mengkomunikasikannya dengan baik. ${ }^{36}$

\section{Pola Komunikasi}

Dilihat dari fakta yang telah digali oleh peneliti. Maka ada dua pola komunikasi yang ada di Pondok Pesantren Miftahul Ulum Banyuputih Kidul, diantaranya:

1. Pola Komunikasi Sirkular

Dalam penelitian ini, pola komunikasi sirkular terlihat dari proses komunikasi interpersonal, komunikasi ini lebih menitikk beratkan pada encoding, decoding yang melaksanakan fungsi-fungsi yang

\footnotetext{
${ }^{35}$ Wawancara dengan Santri Kedua (16/03/2020).

${ }^{36}$ Wawancara dengan Santri Ketiga (08/03/2020)
} 
sama dalam dan sebanding. Dua fungsi pada bagian sumber dan dua fungsi pada bagian penerima. Dalam proses pengiriman pesan dari santri yang berbeda budaya yang satu (komunikator) kepada santri yang lainya (komunikan), kemudian komunikan dapat memberikan respon balikan secara langsung (pada saat itu juga) kepada komunikator. Komunikasi ini biasanya terjadi hampir setiap hari, berlangsung saat santri bertanya secara lisan kepada santri yang berbeda budaya, kedua santri di sini melaksanakan fungsi yang sama yakni sebagai komunikator dan komunikan.

Para pelaku komunikasi di sini memiliki peran ganda, dalam arti pada satu saat bertindak sebagai pengirim pesan, namun pada waktu yang lain berlaku sebagai penerima pesan. Pola komunikasi ini menggambarkan proses komunikasi yang dinamis, di mana pesan transmit melalui proses encoding dan decoding. Umpan balik dalam komunikasi ini sangat penting, karena dengan adanya umpan balik dapat terlihat apakah komunikasinya berhasil atau gagal. Situasi yang sama dengan komunikasi interpersonal adalah komunikasi kelompok, baik komunikasi kelompok kecil maupun kelompok besar. Komunikasi ini biasanya terjadi saat santri berbagi pengalaman dengan santri-santri lain yang kebudayaanya berbeda. Sealain itu juga berlangsung saat pengajian.

2. Pola Komunikasi Linear

Pada tahun 1957 berkembang pola komunikasi linear yang digagas oleh Shannon dan Weaver. Linear mengandung arti lurus yakni perjalanan dari satu titik ke ke titik yang lain secara lurus. Penyampaian pesan kepada komunikan oleh komunikator sebagai titik terminal. Jadi dalam proses komunikasi ini biasanya terjadi dalam tatap muka, tetapi juga dapat digunakan digunakan dalam komunikasi bermedia. Komunikasi linier dalam praktiknya hanya ada pada komunikasi bermedia, tetapi dalam komunikasi tatap muka juga dapat dipraktikkan, yaitu apabila komunikasi pasif, hal ini biasanya terjadi saat pengajian kitab, di mana Ibu Nyai membacakan makna kitab, para santri mendengarkan dan tidak ada satupun santri yang berkomentar maka komunikasi pasif semacam ini termasuk 
dalam pola komunikasi. Terkecuali bila Ibu Nyai mempersilahkan para santri untuk bertanya maka pola komunikasinya akan berubah. ${ }^{37}$

\section{Hambatan Komunikasi}

Dalam setiap proses komunikasi, unsur hambatan tidak pernah ketinggalan, karena komunikasi yang efektif adalah komunikasi yang dapat mengatasi hambatan-hambatan selama melakukan proses komunikasi tersebut. Begitu juga dalam setiap proses komunikasi lintas budaya di pondok pesantren Mifathul Ulum Banyuputih Kidul tidak luput dari gangguan dan hambatan yang terkadang menimbulkan kesalah pahaman.

Hambatan yang mencolok dalam proses komunikasi di pondok pesantren Miftahul Ulum tersebut adalah hambatan semantik atau bahasa. Hambatan bahasa menjadi penghalang utama karena bahasa merupakan sarana utama terjadinya komunikasi. Komunikasi bisa menjadi sulit akibat perbedaan bahasa. Gangguan bahasa ini bisa menimbulkan salah dalam mengartikan suatu pesan. Seperti halnya santri Madura berkomunikasi dengan Santri etnis jawa dengan bahasa khasnya, bahasa khasnya Madura sebagai berikut: Tretan, sengkok seneng beduk tenggeng, yang artinya, saudara, saya suka makan singkong. Di etnis jawa bahasa Beduk itu termasuk bahasa yang sangat kasar, tetapi sebaliknya, di etnis Madura bahasa tersebut sangatlah sopan. Biar tidak timbul kesalahan pahaman sang komunikator harus menjelaskan dengan baik, dengan mamaknai bahasa nasional. ${ }^{38}$

Adapun hambatan dalam proses komunikasi lintas budaya, yaitu awal membaca kitab di dalam pesantren yang menggunakan bahasa Madura yang mana santri dari luar Jawa dan Sumatera itu merasakan kesulitan untuk membacanya, maka memerlukan waktu yang cukup lama untuk bisa beradaptasi membaca dan memaknai kitab, bahkan santri dari Etnis Madurapun merasa kesulitan saat pertama membaca kitab, menurut informan yang merupakan salah satu santri Madura,

${ }^{37}$ Vita Fitriani, Komunikasi Antar Budaya Dalam Kehidupan Pesantren Skripsi Program Studi Ilmu Komunikasi Fakultas Dakwah Institut Agama Islam Negeri Sunan Ampel Surabaya 2013

${ }^{38}$ Wawancara dengan Santri Pertama (08/03/2020) 
bahasa yang dipakai sehari-hari tidak sama dengan bacaan kitab, di kitab lebih kental bahasanya, dari pada bahasa setiap harinya, tetapi santri Madura tidak terlalu sulit membaca hanya berbeda sedikit bahasa.

Menurut informan yang merupakan santri dari etnis Sumatera, waktu pertama mengenal kitab berbahasa Madura, sangatlah sulit dipahami dan kebingungan dan membutuhkan waktu lama untuk memahami tersebut. Cara ampuh untuk bisa memahami bahasa kitab tersebut, dia sering berkomunikasi dengan santri yang dari Madura. Sedangakan santri dari etnis jawa hambatannya sama yaitu di pembacaan kitab. Meskipun dari etnis jawa juga ada bahasa Maduranya tetapi tetap saja tidak ada yang sama antara bahasa kitab dan bahasa sehari-hari. Bacaan Madura kitab ada khas bahasanya tersendiri contohnya dining se anyamah sholat (ini yang dinamakan sholat). ${ }^{39}$

Selain unsur hambatan dalam proses komunikasi Lintas Budaya, terdapat juga unsur pendukung dalam proses komunikasi Lintas Budaya, dalam proses komunikasi Lintas Budaya, kedua pelaku komunikasi harusmenggunkan bahasa yang dimengerti atau bahasa nasional yang sama-sama dimengerti kedua belah pihak. Faktor pendukung yang ditemukan peneliti saat melakukan penelitian di lapangan adalah perbedaan bahasa yang dapat menimbulkan daya tarik tersendiri bagi para santri untuk melakukan komunikasi Lintas Budaya.

Komunikasi Lintas budaya dalam kehidupan pesantren dalam hal ini melalui enam unsur proses komunikasi antarbudaya komunikator, yaitu Komunikan, pesan simbol, media, efek atau umpan balik, suasana, dan gangguan. Komunikan dalam komunikasi lintas budaya adalah pihak yang menerima pesan tertentu, dia menjadi tujuan/sasaran lomunikasi dari pihak lain (Komunikator). Dalam komunikasi lintas budaya, seorang komunikan berasal dari latar belakang sebuah kebudayaan tertentu.

Ingatlah bahwa baik komunikator dan komunikan dalam model komunikasi antarbudaya diharapkan mempunyai perhatian penuh untuk merespon dan menerjemahkan pesan yang dialihkan. Tujuan komunikasi akan tercapain manakala komunikan "menerima" (memahami makna) pesan dari komunikastor dan memperhatikan (attention)serta menerima pesan secara menyeluruh (comprehension). Ini adalah dua aspek penting

${ }^{39}$ Wawancara dengan Santri Ketiga (16/03/2020) 
yang berkaitan dengn cara bagaimana seorang komunikator dan komunikan mencapai sukses dalam pertukaran pesan. Yang dimaksudkan dengan attention adalah proses awal dari seorang komunikan "memulai" mendengarkan pesan, menonton atau membaca pesan itu. Seorang komunikator berusaha agar pesan itu diterima sehingga seperangkat pesan pesan tersebut pelu mendapat perlakuan agar menarik perhatian. Sedangkan yang dimaksud dengan comprehension meliputi cara penggambaran pesan secara lengkap sehingga mudah dipahami dan dimengerti oleh komunikan.

Acapkali seorang komunikan ketika memperhatikan atau memahami isi pesan sangat tergantung dari tiga bentuk pemahaman, yakni: (1) kognitif, komunikan menerima isi pesan sebagai sesuatu yang benar ; (2) efektif, komunikan percaya bahwa pesan itu tidak hanya benar tetapi baik dan disukai, dan (3) overt actionatau tindakan nyata, dimana seorang komunikan percaya atas pesan yang benar dan baik sehingga mendorong tindakan yang tepat. Jadi seorang komunikan dapat bebuat sesuatu untuk memisahkan isi dan perlakuan pesan hanya karena pesan yang diterima itu mengandung attention dan comprehention.

Komunikasi di pondok pesantren yang terjalin antara para santri memiliki kekhasan tersendiri. Beraneka ragama para santri yang ada di dalamnya menimbulkan perbedaan komunikasi dengan komunikasi di luar pesantren. Beraneka ragam di sini tercermin dari berbagai sisi seperti entis, bahasa, suku maupun ras. Komunikasi antarbudaya pada dasarnya mengacu pada realitas keragaman budaya dalam masyarakat yang masing-masing memiliki etika, tata cara dan pola komunikasi yang beragam pula. Seluruh proses komunikasi pada akhirnya menggantungkan keberhasilan pada tingkat ketercapaian tujuan komunikasi, yakni sejauhmana para partisipan memberikan makna yang sama atas pesan yang dipertukarkan. ${ }^{40}$

Komunikasi antarbudaya yang terjadi di Pondok Pesantren Mifatahul Ulum Banyuputih Kidul Jatiroto Lumajang terjadi hampir setiap hari, perbedaan etnis pada mereka menimbulkan perbedaan pula dalam prilaku komunikasi. Dimana Santri yang berasal dari etnis

${ }^{40}$ Alo Liliweri, Makna Budaya dalam Komunikasi Antar Budaya, 227. 
Madura dan Sumatera merupakan entis pendatang yang memberikan warna baru yang dibawa dari kebudayaan keseharian mereka.

Keadaan komunikasi di Pondok Pesantren Mifathul Ulum Banyuputih Kidul Jatiroto Lumajang sangatlah tanggap, dan juga saling memahami satu sama lain, meskipun beda budaya mereka saling menghormati budayanya masing-masing. Sebagaimana penuturan dari santri yang berasal dari Sumatera kehidupan sehari-hari tidaklah luput dari berkomunikasi, dimulai dari sebelum tidur bangun tidur, sekolah, mengaji, bahkan di kamar mandipun berkomunikasi, contoh dikamar mandi berkomunikasi tentang bergantian tempat mandi, karena dipondok pesantren itu tidak luput dari antri, makan pun juga antri.

Sementara itu, dalam proses komunikasi, pesan berisi ide atau gagasan, perasaan yang dikirim komunikator kepada komunikan dalam bentuk simbol. Simbol adalah sesuatu yang digunakan untuk mewakili maksud tertentu, misalnya dalam kata-kata verbal yang diucapkan atau ditulis, atau simbol non verbal yang diperagakan melalui gerak gerik tubuh anggota tubuh, warna, artifak, gambar, pakaian dan lain-lain yang semuanya harus dipahami secara konotatif.

Dalam model komunikasi antarbudaya, pesan adalah apa yang diletakkan atau yang dialihkan oleh komunikator kepada komunikan. Setiap pesan sekurang-kurangnya mempunyai dua aspek utama: content dan tretment, yaitu isi dan perlakuan. Isi pesan meliputi aspek daya tarik pesan, misalnya kebaruan, kontroversi, argumentatif , rasional bahkan emosional. Anda munkin tertarik atas cerita dengan tentang bagaimana pribumi hangusan kota dili stetelah pengumuman hasil jajak pendapat di timor timur pada tahun 1999, namun mungkin anda akan lebih tertari lagi jika cerita itu diserai foto-foto atau pemutaran video tentang kota Dili yang telah menjadi puing-puing. Jadi aspek daya tarik pesan saja tidak cukup, akan tetapi sebuah pesan juga perlu mendapat perlakuan, perlakuan atas pesan berkaitan dengan penjelasan atau penataan isi pesan oleh komunikator. Pilihan isi dan perlakuan atas pesan tergantung dari ketrampilan komunikasi,sikap, tingkat pengetahuan, posisi dalam sistem sosial dan kebudayaan. Salah satu kebutuhan pokok manusia. Manusia 
memang satu satunya hewan yang menggunakan lambang, dan itulah yang membedakan manusia dengan makhluk lainnya. ${ }^{41}$

Setiap interaksi pasti ada peristiwa komunikasi, dan setiap komunikasi pasti bisa dimaknai, karena ada pesan yang ingin disampaikan oleh komunikator kepada komunikan. Model komuikasi publisitas sebagai transportasi dan metafora kontrol dengan memindahkan paradigma berfikir orang dari satu titik ke titik yang lain. $^{42}$

Pesan simbol di Pesantren Mifathul ulum ada simbol komunikasi yang mempunyai makna sebagai tanda simbol kegiatan yang dilakukan secara bersamaan oleh semua santri dipondok. Simbol tersebut adalah penekanan bel, oleh ustadzah atau pengurus Pondok Pesantren Mifatahul Ulum. Bel tersebut di bunyikan setiap kali menjelang waktu shalat, dan waktu-waktu kegiatan lainnya. Ada beberapa macam bunya bel diantara: saat bel berbunyi panjang satu kali adalah tanda waktunya shalat berjamaah, bel berbunyi panjang dua kali persiapan untuk melakukan kegiatan mengaji, bernunyi bel tiga kali panjang adalah tanda santri harus berada di tempat kegiatan tersebut, berbunyi bel 1 kali pendek adalah tanda santri untuk menyelesaikan kegiatannya. ${ }^{43}$

Dalam proses komunikasi anatarbudaya, media merupakan tempat, saluran yang dilalui oleh pesan atau simbol yang dikirim melalui media massa (cetak) seperti majalah, surat kabar dan buku, media massa elektronik (radio, televisi, video, film, dan lain-lain). Akan tetapi kadang-kadang pesan-pesan itu dikirim tidak melalui media, terutama dalam komunikasi antarbudaya tatap muka.

Para ilmuwan sosial menyepakati dua tipe saluran; (1) sensori channel atau saluran sensoris, yakni saluran yang memindahkan pesan sehingga akan ditangkapkan oleh lima indra, yaitu mata, telinga, tangan, hidung, dan lidah. Lima saluran sensoris itu adalah cahaya, bunyi, perabaan, pembauan, dan rasa. (2) institutionalized means, atau saluran

\footnotetext{
${ }^{41}$ Dedy Mulyana, 2018. Ilmu Komunikasi suatu pengantar. Bandung: Remaja Rosdakarya . 92.

${ }^{42}$ Rudi Hartono, Pola Komunikasi Di pesantren, Jurnal Dakwah dan Komunikasi, Volume 1 , nomor 1, januari 2016.

${ }^{43}$ Wawancara dengan Santri Ketiga (08/03/2020).
} 
yang sudah sangat dikenal dan digunkan manusia, misalnya percakapan tatap muka, material cetakan dan media elektronik. Perlu diingat bahwa setiap saluran institusional memerlukan dukungan satu atau lebih saluran sensoris untuk memperlancar pertukan pesan dari komunikator kepada komunikan.

Perhatikan, tatkala manusia bertatap muka (medium institutional) maka orang akan memakai bahasa isyarat tubuh dan pernyataan wajah (kita menangkap pesan itu dengan mata), lalu menangkap bunyi (suara atau gangguan lain), dan mungkin juga meraba, menciumi bau dengan hidung atau merasakan sesuatu dengan lidah. Para ilmuwan sosial juga menyimpulkan bahwa komunikan akan lebih menyukai pesan yang idsampaikan melalui kombinasi dua atau lebih saluran sensoris (perhatikan kalau orang lebih suka menonton tv, mebaca surat kabar dari pada mendengarkan radio).

Dalam unsur komunikasi Lintas Budaya dikehidupan pesantren juga terkadang menggunakan media elektronik yaitu menggunakan microphone yang biasa di gunakan oleh ustadzah atau pengurus Pondok yaitu untuk menyiarkan saat wali santri mengunjungi santri, dan ustadzah pun menggunakan bahasa Madura. Untuk santri yang tidak mengerti dengan bahasa Madura oleh teman santri yang paham bahasa tersebut di beri tahu bahwasannya ada kunjungan dari wali santri. ${ }^{44}$

Manusia mengkomunikasikan pesan karena dia mengharapkan agar tujuan dan fungsi komunikasi itu tercapai. Tujuan dan fungsi komunikasi, termasuk komunikasi antarbudaya, antara lain memberikan informasi, menjelaskan atau menguraikan tentang sesuatu, memberikan hiburan, memaksakan pendapat atau mengubah sikap komunikan. Dalam proses seperti itu kita umumnya menghendaki reaksi balikan, kita sebut umpan balik. Umpan balik merupakan tanggapan balik dari komunikan kepada komunikator atas pesan-pesan yang telah disampaiakan. Tanpa umpan balik atas pesan-pesan dalam komunikasi antarbudaya maka komunikator dan komunikan tidak bisa memahami ide, pikiran dan perasaan yang tergandung dalam pesan tersebut.

Dalam kasus komunikasi tatap muka, umpan balik lebih mudah diterima. Komunikator dapat mengetahui secara langsung apakah

${ }^{44}$ Wawancara dengan Ustadzah Pertama (16/03/2020). 
serangkaian pesan itu dapat diterima oleh komunikan atau tidak. Komunikator pun dapat mengatakan sesuatu secara langsung jika dia melihat komunikan kurang memeberikan perhatian atas pesan yang sedang disampaiakan. Reaksi-reaksi verbal dapat diungkapkan secara langsung oleh komunikan melalui kata-kata menerima, menegerti bahkan mungkin menolak pesan, sebaliknya reaksi pesan dapat dinyatakan dengan pesan non verbal seperti menganggukkan kepala tanda setuju dan menggelengkan kepala sebagai ungkapan tidak setuju.

Umpan balik di kehidupan pesantren lebih mudah diterapkan oleh sesama santri tetapi tidak dengan Ibu Nyai dan ustdzah guru ngaji. Jika sesama santri bisa sangat mudah umpan balik untuk diterima, sedangkan umpan balik dengan ustadzah maupun Ibu Nyai menunggu di persilahkan berbicara oleh Ibu Nyai ataupun ustdzah, dikarenakan jika tidak menunggu dipersilahkan Ibu Nyai atau ustdzah kesannya tidak sopan. Hambatan umpan balik dengan ustdzah dan Ibu Nyai tersebut di bebankan oleh santri yang beretnis Sumatera. Dikarenakan saat berkomunikasi dengan ustadzah dan Ibu Nyai ada yang tidak dipahami sulit untuk bertanya, jadi harus bertanya kepada teman yang sudah sangat memahami bahasa tersebut.

Satu faktor penting dalam komunikasi antarbudaya adalah suasana yang kadang-kadang disebut setting of comunication yakni tempat (ruang, space) dan waktu (time) serta suasana (sosial psikologis) ketika komunikasi antarbudaya berlangsung. Suasana itu berkaitan dengan waktu (jangka pendek/panjang,jam/hari/minggu/bulan/tahun) yang tepat untuk bertemu/berkomunikasi sedangkan tempat (rumah, kantor, rumah ibadah) untuk berkomunikasi, kualitas relasi (formlitas, informalitas) yang berpengaruh terhadap komunikasi antarbudaya. Pondok Pesantren bisa disebut juga dengan rumah ibadah, karena di dalam Pondok tersebut tidak hanya untuk berpindah tempat tidur dari rumah pindah tempat tidur di asrama. Di dalam pondok pesantren tidak luput dari mencari ilmu yang barokah, beribadah, dengan mudah mencari pahala, setiap harinya selalu tidak luput oleh beribadahh dan beribadah.

Komunikasi di Pondok Pesantren Mifathul ini sangat menekankan bahasa Madura disamping kitabnya berbahasa Madura kebiasaan dan keseharianpun kebanyakan menggunakan bahasa Madura dan 
pendirinya juga termasuk dari etnis Madura, jadi dari etnis-etnis selain Madurapun sampai sangat memahami bahasa Madura karena sudah terbiasa hidup di lingkungan yang beretnis Madura. ${ }^{45}$

Gangguan dalam komunikasi antarbudaya adalah segala sesuatu yang menjadi penghambat laju pesan yang ditukar antara komunikator dengan komunikan, atau paling fatal adalah mengurangi mana pesan antarbudaya. Gangguan menghambat komunikan menerima pesan dan sumber pesan. Gangguan (noice) dikatakan ada dalam satu sistem komunikasi bila dalam membuat pesan yang disampaiak berbeda denga pesan yang diterima. Gangguan itu dapat bersumber dari unsur-unsur komunikasi, misalnya komunikator, komunikan, pesan, media/saluran yang menurangi usaha bersama untuk memberikan makna yang sama atas pesan.

Gangguan komunikasi yang bersumber dari komunikator dan komunikan misalnya karena perbedaan status sosial dan budaya (stratifikasi, sosial, jenis pekerjaan, faktor usia), latar belakang pendidikan (tinggi pendidikan) dan pengetahuan (akumulasi pengetahuan terhadap tema yang dibicarakan), ketrampilan (kemampuan untuk memanipulasi pesan) berkomunikasi. Sementara itu gangguan yang berasal dari pesan misalnya perbedaan pemberian makna atas pesan yang disampaikan secara verbal, (sinonim, homonim, denitatif dan konotatif), perbedaan tafsir atas pesan non verbal (bahasa isyarat tubuh). Gangguan dari media/saluran karena orang salah memilih media yang tidak sesuai dengan konteks yang kurang mendukung terlaksanakannya komunikasi antarbudaya.

\section{KESIMPULAN}

Dari berbagai data dan fakta yang sudah diperoleh dari lapangan dan dikonfirmasikan dengan teori-teori yang menjadi acuan peneliti yang sudah diuraikan dalam skripsi ini, maka penulis mencoba memberikan simpulan mengenai beberapa fokus penelitian yakni tentang prilaku dan pola komunikasi antarbudaya antara santri etnis Jawa, Madura dan Sumatera di Pondok Pesanten Miftahul Ulum Banyuputih Kidul.

${ }^{45}$ Wawancara dengan Santri Ketiga (16/03/2020). 
Perilaku komunikasi antarbudaya antara santri etnis Jawa, Madura dan Sumatera di Pondok Pesantren Miftahul Ulum Banyuputih Kidul dapat dilihat dari dua konteks yaitu konteks sosial dan konteks kemanusiaan. Dari konteks sosial perilaku komunikasi para santri tidak banyak menunjukkan adanya perbedaan atau diskriminasi antara santri yang beretnis Jawa, Madura maupun Sumatera, mereka sama-sama saling menghargai atau menghormati budaya satu sama lain. Dan dari konteks kemanusiaan nilai-nilai kemanusiaan yang mereka terapkan dalam kehidupan sehari-hari di atas perbedaan budaya adalah mereka saling menjaga sikap atau etika mereka. Meskipun mereka mempunyai jalan pikiran yang berbeda dan juga sistem beretika yang tradisional artinya hanya berlaku bagi kelompok atau etnis tertentu, seperti Madura, Jawa dan Sumatera

Pola komunikasi antarbudaya antara santri etnis Jawa, Madura dan Sumatera di Pondok Pesantren Miftahul Ulum Banyuputih Kidul adalah pola komunikasi sirkular dan pola komunikasi linear, komunikasi sirkular lebih menitikberatkan pada encoding, decoding yang melaksanakan fungsi-fungsi yang sama dalam dan sebanding. Dua fungsi pada bagian sumber dan dua fungsi pada bagian penerima. Dalam proses pengiriman pesan dari santri yang berbeda budaya yang satu (komunikator) kepada santri yang lainya (komunikan), kemudian komunikan dapat memberikan respon balikan secara langsung (pada saat itu juga) kepada komunikator. Sedangkan komunikasi linear komunikasi berjalan secara lurus dan dengan adanya perbedaan strata antara komunikator (Ibu Nyai) dan komunikan (santri), selain itu dalam pola komunikasi linear proses komunikasi berjalan searah atau umpan balik tidak menjadi prioritas utama, tetapi yang terpenting pasan harus tersampaikan.

Hambatan yang mencolok dalam proses komunikasi di pondok pesantren Miftahul Ulum tersebut adalah hambatan semantik atau bahasa. Hambatan bahasa menjadi penghalang utama karena bahasa merupakan sarana utama terjadinya komunikasi. Gagasan, pikiran, dan perasaan dapat diketahui maksutnya ketika disampaikan lewat bahasa. Gangguan bahasa ini bisa menimbulkan salah dalam mengartikan suatu pesan sedangkan faktor pendukungnya adalah pebedaan bahasa yang 
dapat menimbulkan daya tarik tersendiri bagi para santri untuk melakukan komunikasi antarbudaya.

\section{DAFTAR PUSTAKA}

Abdullah, Irwan. (2009). Kontruksi dan Reproduksi Kebudayaan. Yogyakarta: Pustaka Belajar

Arifin, Zainal. (2011). Penelitian Pendidikan (Metode Dan Paradigma Baru). Bandung: PT Remaja Rosdakarya

Dedy Mulyana. (2018). Ilmu Komunikasi suatu pengantar. Bandung: Remaja Rosdakarya

Departemen Agama RI. (2003). Pondok Pesantren dan Madrasah Diniyah. Jakarta: Departemen Agama RI

Djazilam. M. Syukron. (2019). Relevansi Sistem Pendidikan Pesantren Tradisional Dalam Era Modernisasi. Al-Insyiroh: Jurnal Studi Keislaman, 5 (1), 89-105.

Fitriani, Vita. (2013). Komunikasi Antar Budaya Dalam Kehidupan Pesantren. Skripsi, Program Studi Ilmu Komunikasi Fakultas Dakwah, Institut Agama Islam Negeri Sunan Ampel, Surabaya, Indonesia, 2013

Fuady, Ahmad Syauqi. (2020). Pembaharuan Sistem Pendidikan Di Pesantren”. Al-Insyiroh: Jurnal Studi Keislaman, 6, (1), 101-114.

Hartono, Rudi. (2016). Pola Komunikasi Di Pesantren, Al-Balagh: Jurnal Dakwah dan Komunikasi, 1 (1), 67-100.

Herdiansyah, Haris. (2011). Metodologi Penelitian Kualitatif. Jakarta: Salemba Humanika.

Koentjaraningrat. (2002). Kebudayaan Mentalitas dan Pembangunan, Jakarta: PT Gramedia Pustaka.

Liliwei, Alo. (2005). Prasangka \& Konflik Komunikasi Lintas Budaya Masyarakat Multikultural. Yogyakarta: PT LkiS.

Liliweri, Alo. (2009). Makna Budaya dalam Komunikasi Antar Budaya. Yogyakarta: PT LKiS Printing Cemerlang.

Margono, S. (2005). Metodologi Penelitian Pendidikan. Jakarta: Rineka Cipta

Moeloeng, Lexy J. (2008). Metode Penelitian Kualitatif. Bandung: Remaja Rosdakarya 
Nuruddin. (2010). Sistem Komunikai Indonesia. Jakarta: PT Raja Grafindo Persada

Pohan, Rusdi. (2007). Metodologi Penelitian Pendidikan. Yogyakarta: Lanakarya

Putra, M. Kholil Baita. (2015). Eksistensi Sistem Pesantren Salafiyah Dalam Menghadapi Era Modern". Al-Insyiroh: Jurnal Studi Keislaman, 1 (1), 87-104

Rachman, R. F. (2020). Kebijakan Pendidikan Anak Berkebutuhan Khusus Di Surabaya Dalam Perspektif Islam. Bidayatuna: Jurnal Pendidikan Guru Mandrasah Ibtidaiyah, 3 (1), 125-143.

Rachman, R. F. (2019). Optimalisasi Media Digital Berbasis Kemaslahatan Umat dalam Program Pahlawan Ekonomi Surabaya. IQTISHODUNA: Jurnal Ekonomi Islam, 8 (2), 273-292

Rachman, R. F. (2019). Pengembangan Industri Kreatif Berbasis Media Digital di Surabaya dalam Perspektif Islam. KOMUNITAS, 10 (2), 157-176.

Rachman, R. F. (2019). Optimalisasi Teknologi Komunikasi Informasi Command Center Bagi Efektifitas Tenaga Kesejahteraan Sosial Kecamatan. Dakwatuna: Jurnal Dakwah dan Komunikasi Islam, 5 (2). $170-180$

Rachman, R.F. (2018). “Perspektif Karen Armstrong Tentang Islamofobia Di Media Barat. Dakwatuna: Jurnal Dakwah dan Komunikasi Islam, 4 (2), 282-291.

Ramdhan, T. W. (2018). Islam Nusantara: Pribumisasi Islam ala NU. AlInsyiroh: Jurnal Studi Keislaman, 2(1), 73-91..

Robby I, Chandra. (1992). Konflik Dalam Hidup Sehari-hari. Yogyakarta: Kansius

Salim, Agus. (2006). Stratifikasi etnik, Yogyakarta: Tiara Wacana, 2006)

Soerjono, Soekanto. (1974). Faktor-Faktor Dasar Interaksi Sosial dan Kepatuhan Pada Hukum. Hukum Nasional, Nomor 25,

Soerjono, Soekanto. (2012). Sosiologi Suatu Pengantar, Jakarta: PT Rajagrafindo Persada 
Sugiyono. (2010). Metode Penelitian Pendidikan Pendekatan Kuantitatif, Kualitatif dan $R \& D$, Bandung: Alfabeta.

Suprayogo, Imam \& Tobroni. (2001). Metode Penelitian Sosial Agama. Bandung: Remaja Rosdakarya 